Southeast Asian Journal of Islamic Education Management

Vol. 1 No. 2 (2020),pp 146-151

http://sajiem.iainponorogo.ac.id/sajiem
p-ISSN: 2716-0599

e-ISSN: 2715-9604

\title{
Manajemen Karakter Peserta Didik Pesantren di Era Pandemi (Studi Kasus Smp Pesantren Modern Terpadu Prof. Dr. Hamka II Padang)
}

\author{
Wahyu Fitrina Defi \\ STAIN Mandailing Natal, Indonesia \\ wahyufitrinadefi93@gmail.com
}

DOI: https://doi.org/10.21154/sajiem.xxxxxxx

\begin{tabular}{|l|l|l|}
\hline Received:oomonth 2019 & Revised: oomonth 2019 & Approved:oomonth 2019 \\
\hline
\end{tabular}

\begin{abstract}
Abstrak
Karakter merupakan poin terpenting yang harus dicapai dalam proses pembelajaran dan ini sesuai dengan kurikulum yang diusung di era kini. Proses pembelajaran yang berlangsung biasanya, face to face pada lembaga pesantren yang notabene kehidupannya dikontrol selama dua puluh empat jam kini mulai berubah di era pandemi ini. Virtual learning process membuat semua aspek yang terkait untuk terbiasa secara online pada setiap kegiatan belajar mengajar di pesantren. Walaupun proses pembelajaran yang berlangsung secara virtual namun kontrol terhadap perilaku peserta didik sebagai bagian dari karakter tetap diupayakan agar sama porsinya dengan proses pembelajaran secara langsung. Metode penelitian menggunakan pendekatan kualitatif dengan pendekatan studi kasus. Teknik pengambilan data dilakukan dengan wawancara, observasi dan studi dokumentasi. Data dianalisis melalui tiga tahapan yaitu reduksi data, presentasi data, dan penarikan kesimpulan. Informan penelitian adalah kepala sekolah, guru kelas, wali kelas, guru pesantren, dan kepala pesantren. Adapun temuan penelitian terkait manajemen karakter peserta didik di SMP Pesantren Modern Terpadu Prof. Dr. Hamka II Padang adalah: 1) Perencanaan karakter, 2) Pelaksanaankarakter, 3) Pengorganisasian karakter, 4) Pengevaluasian karakter dengan berbasis virtual via whatsapp, video pembelajaran, dan google classroom. Selain itu pembentukan tim dalam kontrol karakter di pesantren ini diperlukan dan dengan istilah "Hamka Peduli".
\end{abstract}

Kata kunci: manajemen, karakter, pesantren, virtual

\section{Pendahuluan}

Karakter sudah layaknya menjadi perhatian khusus semenjak Kurikulum 2013 mulai diusung sampai sekarang. Implementasinya mulai tertuang pada perencanaan pembelajaran yang dibuat 
oleh guru pada mata pelajarannya masing-masing sesuai dengan apa yang diharapkan dari peserta didik dan diukur pula berdasarkan situasi serta kondisi peserta didik masing-masing. Kemudian penekanan pada pencapaian karakter dalam proses pembelajaran mulai diperjelas oleh Nadiem Makarim dalam kebijakannya merdeka belajar. Pengukuran terhadap aspek karakter inipun paling krusial sebagai bahan pertimbangan bagi peserta didik untuk lanjut ke tahapan atau tingkat pendidikan selanjutnya.

Begitu krusialnya kedudukan karakter dalam proses pembelajaran membuat guru harus benar-benar mampu menyentuh sampai ke akar-akarnya perihal karakter ini, yang tercakup dalam proses pembelajaran yang sudah dicanangkan oleh guru yang bersangkutan. Rencana Proses Pembelajaran (RPP) namanya. Dalam RPP ini terangkum jelas proses pembelajaran dari awal sampai akhir termasuk aspek karakter mana yang hendak dicapai sampai proses evaluasi yang seperti apa yang akan diterapkan.

Sejak diterapkannya kurikulum 2013 yang menekankan kepada karakter dan dibarengi dengan muncul kebijakan merdeka belajar, tampaknya guru-guru sudah mulai terbiasa dengan metode pembelajaran yang akan diterapkan dalam proses pembelajaran. Guru-guru sudah mulai dilatih untuk pengembangan ke arah hal tersebut baik secara personal maupun melalui komunitas-komunitasnya. Proses pembelajaran mulai mengarah kepada pembelajaran kontekstual era kini. Tidak terkecuali terhadap sekolah yang berbasis pesantren. Seperti yang sama-sama kita ketahui bahwa penekanan pesantren tidak hanya pada pembentukan karakter secara umum saja, namun juga pada pencapaian karakter secara religius.

Namun era kini, masa pandemi covid 19 mulai menggeser paradigma proses pembelajaran yang biasanya berlangsung secara tatap muka berubah menjadi daring. Banyak fitur-fitur online yang nampaknya menjadi pengganti pembelajaran tatap muka seperti whatsapp, moodle, google classroom, zoom meeting, schoology dan aplikasi lainnya yang mendukung pembelajaran. Pergeseran ini juga mulai memunculkan tantangan bagi guru dalam melakukan kontrol dan evaluasi terhadap karakter peserta didik, karena ruangnya sudah mengalami perubahan, tidak tatap muka lagi. Biasanya kedisiplinan peserta didik dapat diukur melalui ketepatan waktunya datang ke sekolah, mengerjakan pekerjaan rumah tepat waktu namun sekarang hal ini menjadi kendala bagi sebagian guru terkait proses evaluasinya, terlebih jika peserta didiknya banyak dari kalangan ekonomi ke bawah dan berada pada daerah yang tidak support dengan jaringan internet. Begitu juga dengan ketercapaian karakter peserta didik sebagai santri. Agak susah 
rasanya untuk mengontrol peserta didik yang sudah melaksanakan ibadah wajib dan sunat lainnya. ${ }^{1}$

Walaupun demikian rumitnya permasalahan daring ini, terutama kepada pembentukan karakter, perlu dilakukan berbagai upaya untuk mengatasinya agar tujuan awal pendidikan yang secara garis besarnya adalah pembentukan karakter tetap dapat tercapai dan dilaksanakan walau dalam keadaan apapun. Manajemen karakter merupakan tindakan yang tepat untuk permasalahan ini.

\section{Manajemen, Pendidikan, dan Karakter}

Karakter merupakan pola perilaku yang dimunculkan oleh seseorang dalam berinteraksi. Wyne (dalam Mulyasa, 2011:3) mengemukakan bahwa karakter merupakan aplikasi nilai-nilai yang "baik" dalam keseharian dan tertuang dalam tindakan nyata/perilaku seseorang. ${ }^{2}$ Seseorang akan dikatakan memiliki karakter jika memiliki komponen "nilai-nilai yang baik", peduli dengan sesama, tepat waktu dan tidak malas, percaya diri ketika menampilkan hasil karyanya, berkata dan berperilaku yang sebenarnya sebagai contoh.

Pembentukan karakter seseorang diperoleh melalui pembiasaan dan tidak serta merta langsung tercapai sesuai dengan yang diharapkan. Hasan (2010:6) mengemukakan bahwa pembentukan karakter dapat dilakukan dengan pendidikan secara terpogram, bertahap, dan berkesinambungan. ${ }^{3}$ Singkatnya seseorang berkarakter memalui proses yang panjang. Proses inilah yang diistilahkan dengan pendidikan. Pendidikan karakter merupakan penciptaan lingkungan sekolah yang membantu peserta didik dalam perkembangan etika, tanggung jawab melalui model dan pengajaran karakter yang baik melalui nilai-nilai universal (Berkowitz dan Bier, $2005: 7)^{4}$

Agar karakter yang terbentuk jelas dan terarah, perlu upaya manajemen sebagai alatnya. Manajemen merupakan tindakan pengelolaan yang dilakukan terhadap sesuatu agar tujuan semula dapat dicapai. George R Terry (dalam Sukarna, 2011 : 3) mengemukakan bahwa adalah usaha mencapai tujuan dengan usaha secara bersama-sama. Lebih lanjut ia juga mengemukakah bahwa manajemen dapat dilihat prosesnya pada empat aspek yaitu plannig/perencanaan, organizing/pengorganisasian, actuating/pelaksanaan, dan evaluating/pengevaluasian ${ }^{5}$. Tidak hanya lembaga yang dimanajemeni, karakter sebagai wujud perilaku yang memang tidak terlihat juga perlu dimanejemeni. Apalagi pola pembelajaran di era pandemi ini mulai bergeser dengan 
mengintegrasikan teknologi informasi, tentu pola pembentukan karakter perlu dibarengi juga dengan teknologi informasi.

Secara keseluruhan manajemen, pendidikan dan karakter seperti simpul erat. Karakter merupakan nilai yang hendak dicapai dengan proses pendidikan kemudian dikelola dengan sejumlah strategi manajemen.

\section{Perencanaan Karakter}

Upaya manajemen karakter di SMP Pesantren Modern Terpadu Prof. Dr. Hamka II Padang dimulai dengan membentuk tim terlebih dahulu dengan istilah "Hamka Peduli". Tim ini terdiri dari guru-guru yang memiliki homebased di sekolah maupun pesantren. Satu orang guru-guru memiliki tanggung jawab terhadap sepuluh orang santri yang setiap harinya di bawah pengawasan guru yang bersangkutan.

Tahap perencanaan karakter ini diawali dengan menyepakati nilai-nilai yang menjadi pegangan wajib bagi semua santri. Yang kemudian implementasinya terlihat dari beberapa kebiasaan santri berupa: 1) melaksanakan sholat wajib dan sunat diantaranya sholat tahajud, sholat shubuh, sholat dhuha, sholat zhuhur, sholat ashar, sholat maghrib, sholat isya, sholat tarawih, sholat witir, 2) Tasmi hafalan alquran berdasarkan tingkatannya masing-masing, 3) kegiatan sosial berupa membantu orang-orang yang berada di sekitar santri, 4) penyelesaian materi pembelajaran.

\section{Pelaksanaan Karakter}

Tahap pelaksanaan karakter ini dilakukan dengan mengintegrasikan teknologi informasi. Rata-rata peserta didik SMP Pesantren Modern Terpadu Prof. Dr. Hamka II Padang adalah usia yang baru memasuki remaja. Rata-rata dari mereka terkendala dengan kepemilikian smartphone yang belum merata dan signal di daerah mereka masing-masing. Oleh karena itu ada kesepakatan dari pihak pesantren untuk menggunakan media whatsapp sebagai virtual learning process. Di samping itu, ada beberapa guru mata pelajaran sains yang juga berinisiasi untuk membuat video pembelajaran sebagai panduan bagi peserta didik dalam proses pembelajaran, kemudian video tersebut diunggah ke dalam grup whatsapp yang sudah dibuat per kelas. Sesekali untuk memperkenalkan peserta didik dengan teknologi informasi dan dengan tujuan agar mereka tidak ketinggalan dengan perkembangan teknologi informasi, mereka juga diperkenalkan dengan google classroom. Namun ini tidak diwajibkan bagi semua peserta didik, mengingat tidak semua 
peserta didik yang memiliki aplikasi tersebut di smartphonenya dan memiliki signal yang stabil di daerahnya masing-masing.

Pelaksanaan dalam poin ini lebih disesuaikan dengan situasi dan kondisi peserta didik dan guru. Jika ditemukan kendala terkait pembelajaran virtual ini, maka guru yang bersangkutan dapat menelepon orangtua peserta didik untuk teknis pembelajaran yang dirasa sesuai. Jika ditemukan kendala lagi, maka instruksi by phone ini dari guru kepada peserta didik terkait tugastugas belajar yang akan dilaksanakannya.

Pelaksanaan ini juga diikuti dengan SOP (Standar Operating Procedure) yang ditetapkan oleh kepala sekolah, wakil kepala sekolah dan penjamin mutu agar kegiatan yang berlangsung sesuai standar dan sesuai dengan tujuan semula yakni mampu mengontrol karakter peserta didik walau dalam jaringan.

\section{Pengorganisasian Karakter}

Tahap pengorganisasian karakter ini dilakukan dengan membagi tugas masing-masing guru yang terlibat dalam proses pembelajaran ini termasuk waktu untuk pelaporannya. Guru bertugas sebagai fasilitator peserta didik dan pengarah dalam proses pembelajaran. Kepala sekolah dan pesantren bertugas sebagai evaluator dan pemberi feedback terhadap proses pembelajaran yang telah dilaksanakan.

\section{Pengevalusiaan Karakter}

Sebagai bentuk evaluasi pada proses pembelajaran di SMP Pesantren Modern Terpadu Prof. Dr. Hamka II Padang, semua laporan kegiatan pembelajaran santri dilaporkan kepada dua orang tenaga kependidikan setiap harinya. Kemudian dalam jangka waktu satu bulan akan diteruskan kepada kepala sekolah dan pesantren untuk bahan evaluasi. Bagi peserta didik yang belum mencapai karakter yang diharapkan, maka hasil evaluasi akan diberikan kepada wali kelas dan wali santri untuk seterusnya menghubungi orang tua santri yang bersangkutan agar nantinya ada peningkatan terhadap karakter santri.

\section{Diskusi Pembahasan}

Manajemen merupakan tindakan pengelolaan yang dilakukan terhadap sesuatu agar tujuan semula dapat dicapai. George $\mathrm{r}$ terry (dalam sukarna, 2011 : 3) mengemukakan bahwa adalah usaha mencapai tujuan dengan usaha secara bersama-sama. Lebih lanjut ia juga mengemukakah 
bahwa manajemen dapat dilihat prosesnya pada empat aspek yaitu plannig/perencanaan, organizing/pengorganisasian, actuating/pelaksanaan, dan evaluating/pengevaluasian. ${ }^{6}$

Berdasarkan definisi di atas manajemen bergerak dalam pencapaian tujuan lembaga dengan usaha secara bersama yang dilakukan oleh berbagai komponen dalam suatu lembaga. Pencapaian karakter yang diinginkan oleh SMP Pesantren Modern Terpadu Prof. Dr. Hamka II Padang, bergerak untuk pencapaian karakter secara general dan karakter religius dengan usaha bersamasama dari guru, wali kelas, tenaga kependidikan, kepala sekolah dan pesantren serta pelibatan orang tua peserta didik.

Usaha pembentukan karakter di SMP Pesantren Modern Terpadu Prof. Dr. Hamka II Padang di tengah pandemi dengan mengintegrasikan perkembangan teknologi informasi. Penggunaan media whatsapp lebih sering digunakan dalam rangka menyamaratakan kesempatan belajar online bagi peserta didik yang tidak memiliki smartphone dan berada di daerah dengan signal yang tidak stabil.

\section{Kesimpulan}

Karakter merupakan poin terpenting yang harus dicapai dalam proses pembelajaran. manajemen karakter peserta didik di SMP Pesantren Modern Terpadu Prof. Dr. Hamka II Padang adalah: 1) Perencanaan karakter, 2) Pelaksanaan karakter, 3) Pengorganisasian karakter, 4) Pengevaluasian karakter dengan berbasis virtual via whatsapp, video pembelajaran, dan google classroom. Selain itu pembentukan tim dalam kontrol karakter di pesantren ini diperlukan dan dengan istilah "Hamka Peduli”.

Daftar Pustaka

Azzahra, Nadia Fairuza. Mengkaji Hambatan Pembelajaran Jarak Jauh di Indonesia di Masa Pandemi Covid 19; Center for Indonesian Policy Studies. Ringkasan Kebijakan Nomor 2. Mei 2020: 1-9

Berkowitz and Bear. What Works in Character Education: A Research Driven Guide for Educators. Washington DC : University of Missouri St. Louis. 2005.

Hasan. Pengembangan Pendidikan Budaya dan Karakter Bangsa. Jakarta: Litbang Puskur. 2010

Mulyasa. Manajemen Pendidikan Karakter. Jakarta: Bumi Aksara. 2011.

Sukarna. Dasar-dasar Manajemen. Bandung: Mandar Maju. 2011 